\title{
The production of bedspace: prison privatization and abstract space
}

\author{
M. L. Mitchelson \\ Department of Geography \& Anthropology, Kennesaw State University, Georgia, USA \\ Correspondence to: M. L. Mitchelson (mattmitchelson@gmail.com)
}

Received: 29 March 2014 - Revised: 18 July 2014 - Accepted: 25 July 2014 - Published: 22 December 2014

\begin{abstract}
This paper reports results from a critical discourse analysis of Annual Reports for Corrections Corporation of America and Geo Group, Inc. (formerly Wackenhut), the two largest private prison firms currently operating in the United States. Considerable geographic scholarship has analyzed privatization, on the one hand, and imprisonment, on the other. However, geographers have paid less attention to explicitly for-profit imprisonment. In particular, geographers have overlooked or ignored the emergence of bedspace, a concept that now pervades penal discourse. Rather than continuing conventional public-versus-private prison debates, this paper identifies bedspace as the discursive common ground upon which private prison industrialists and the state actually converge. Applying Henri Lefebvre's theorization of "abstract space" to imprisonment, I argue that the discursive creation of bedspace produces a nondialectical representation of space that is fully commodified and bureaucratized. However, the paper concludes that this nondialectical space problematically severs the immanently human geography of imprisonment, which is a "messy" space that is always lived and experienced in particular ways, from its inanimate architectural infrastructure (i.e., beds). Beyond the potential ethical and empirical challenges raised by the production of such an abstract space, bedspace signals the discursive and material convergence of state punishment with capital flows that build and often move beyond prison boundaries while obscuring violent geographies.
\end{abstract}

\section{Introduction}

This paper presents a critical discourse analysis of annual reports from the world's largest private prison companies: Corrections Corporation of America (CCA) and the Geo Group, Inc. (Geo Group), firms with combined reported revenues in 2013 of more than USD 3.2 billion (CCA, 2014; Geo Group, 2014). My goal is to apply arguments from Lefebvre ([1974] 1991) and subsequent scholars (Brenner and Elden, 2009; Jones and Popke, 2010; McCann, 1999) regarding the production of space to a new spatial context: the private prison industry, and the broader carceral context in which it is situated. In what follows I argue that private prison firms utilize a distinct and problematic spatial epistemology, which presents a fundamentally violent production of social space as a nondialectical and a-political spatiality (Jones and
Popke, 2010; Tyner and Inwood, 2014). This spatial epistemology is signified by the term bedspace (Loyd et al., 2010). ${ }^{1}$

Private prison firm executives often illustrate the general meaning of bedspace for the private prison industry. For example, a CCA letter to shareholders explains that their "inventory of beds provides CCA with a competitive advantage for winning new contract awards" (CCA, 2009:5 [emphasis added]). Similarly, two Geo Group leaders (2007:4) write that

Our organic growth pipeline remains strong with thirteen projects currently under development with

\footnotetext{
${ }^{1}$ Please note that I will use the term bedspace to signify three specific terms, which are often used interchangeably, bed $(s)$, bed space, and bedspace; however, all direct quotes remain unchanged. Please also note that, although there are other usages of the term (e.g., rent per bed space), this paper is focused exclusively on carceral settings in which human beings are detained or confined by other human beings against their will.
} 
more than 8,200 beds and representing approximately $\$ 13.7$ million in annualized operating revenues. In addition to these projects under development, which we believe to be the largest organic growth pipeline in our industry, we are currently marketing approximately 900 immediately available beds... [emphasis added].

I argue that bedspace represents geographies of imprisonment - what are immanently human geographies (Martin and Mitchelson, 2009) - as an inventory of furniture. In turn, this paper is motivated by the following research question: what work is done by this curious representation of space (i.e., bedspace)?

\section{Analyzing the production of abstract space and prison privatization}

My empirical findings suggest that bedspace functions as a form of what Lefebvre called "abstract space" (Gregory, 1994:401-402; Lefebvre, [1974] 1991:49-53). Lefebvre argued for a specific, dialectical understanding of space (Brenner and Elden, 2009; Jones and Popke, 2010; Lefebvre, [1974] 1991; Tyner and Inwood, 2014), in which "abstract" and "concrete" space are locked in tension. Whereas concrete space entails the everyday processes of life, abstract space is produced through the commodification and bureaucratization of concrete space (Gregory, 1994:401-406). For example, a direct observer of the concrete space of life in and around the Jenkins Correctional Facility (Georgia, USA) might witness phone calls home, conversations amongst correctional officers during shift change, an exchange of contraband, meals eaten, acts of violence, visitations, a group of new prisoners arriving, a group of former prisoners leaving, or any number of interactions between the people in that place and their environment. However, Jenkins Correctional can be selectively simplified and represented as an abstract space, described as 1124 beds (CCA, 2014:11), or 1.3\% of a firm's 86000-bed inventory (CCA, 2014:5).

McCann defines abstract space as "space represented by elite social groups as homogeneous, instrumental, and ahistorical in order to facilitate the exercise of state power and the free flow of capital" (1999:164). These key characteristics of abstract space (i.e., homogeneity, instrumentality, and the absence of historical context) in service to commodification and bureaucratization structure the empirical findings and analysis below. I contend that recent annual reports and other secondary sources for CCA and the Geo Group contain instrumental representations of space authored from the vantage point of elite social groups, such as the firms' corporate executives and leadership. These sources are also authored with two elite social groups as their intended audience: the U.S. Securities and Exchange Commission and the firm's shareholders. In turn, these documents provide a rich archive of material through which to analyze the production of abstract space in a carceral context.

Again, bedspace is produced though the commodification and bureaucratization of space. Because these processes neither start nor end "within" private prisons, these documents lead beyond the walls of a privately owned or managed prison, to a broader socio-spatial context: what is often referred to as "mass imprisonment" (Garland, 2001). Ultimately, these findings underscore the importance of that which bedspace cannot say about the violence characteristic of the lived space that it claims to represent (i.e., imprisonment).

The remainder of this paper is divided into three sections. In the following section I review literatures centered on prison privatization debates and carceral geographies. In the paper's third section I present the paper's empirical and analytical contribution to these literatures. Specifically, I identify and analyze spatial representations from private prison firm writings that I argue present imprisonment as a homogeneous, instrumental, and ahistorical spatiality. Bedspace is only one representation of space, however pervasive and powerful it may be. Thus, these findings call for additional geographic representations - and political possibilities - for prison space. In the paper's concluding section, I hope to inspire a discussion regarding the empirical and analytical silences that I fear are imposed by a bedspace epistemology, and to help reimagine the prison's political potential.

\section{Literature review}

\subsection{Conventional prison privatization debates}

Until now, spatial epistemologies such as bedspace have not been treated in the prison privatization literature. And, although geographers have written extensively on privatization (e.g., special issues of Antipode (vol. 39, issue 3) and Capitalism Nature Socialism (vol. 16, issue 1)), the private prison has not attracted much attention. Beyond the discipline, advocates and critics of prison privatization generally take one of two approaches to the same question: should prisons be owned and operated by private contractors, or should prisons be exclusively public institutions? Dolovich (2005) describes these approaches as the "inherent-public-function" and the "comparative efficiency" approach; the former is a normative claim, which attracted greater attention during the industry's infancy; the latter appears as an empirical question, and it attracts most of the time and energy in current debates.

The inherent-public-function approach questions the legitimacy of the private prison as a social institution (Dolovich, 2005). The comparison implicit in this approach normalizes the prison as a public good and pits it against private interests. This approach to prison privatization takes place in explicitly normative terms, and other scholars have noted "the numerous attempts to paint the private prison as something that is inherently obnoxious on general norma- 
tive grounds" (White, 2001:136). Privatization's critics in this camp pose arguments against privatization in terms of morality, accountability, or legality (e.g., DiIulio and John, 1988). Economistically focused advocates of prison privatization often brush inherent-public-function approaches aside as "ideological positions" (Harding, 1999:109). The implicit counter-argument here is that prison ownership and operation are best determined by a free market (i.e., an ideological position). The positions are more or less irreconcilable.

The comparative efficiency approach frames cost as the central issue of concern (Clear and Frost, 2002:425; GAOGGD, 1991:3; Shichor, 1998:82). Advocates argue that privatization reduces the costs of building and operating prisons, relative to the public sector (cf. Austin and Coventry, 1999). Critics either argue that the evidence of cost savings is inconclusive (cf. GAO, 2007), or that private prisons reduce the quality of imprisonment or services for both prisoners and employees (e.g., Taylor and Cooper, 2008). The inaccessibility of prisons, a dearth of data, and methodological problems beleaguer comparative efficiency studies, and the argument over which sector is more efficient proceeds without a conclusion in sight (GAO, 2007; Greene, 1999).

There are clear faults with the parameters of conventional prison privatization debates (cf. Dolovich, 2009), and three are particularly relevant to the argument at hand. First, the space at stake in prison privatization debates is most often represented as homogeneous. With notable exceptions (e.g., Bates, 1998; Taylor and Cooper, 2008), arguments for and against prison privatization are seldom grounded in experiences or outcomes in specific places. Second, the instrumentality of prison space is seldom questioned by either side of the debate. For example, privatization's critics generally avoid concerns regarding the broader legitimacy of imprisonment raised by prison abolitionists (Gilmore and Gilmore, 2008; Loyd, 2012). Specifically, approaches to the debate that privilege efficiencies in the form of cost savings generally ignore the fact that the least-costly prison is neither public nor private, but unoccupied (or un-built). Third, the terms of conventional prison privatization debates are often presented ahistorically in that they assume mass imprisonment - a context in which more than two million people are imprisoned on any given day - as the baseline from which to stake normative claims or measure and compare efficiencies (Dolovich, 2005, 2009). In sum, the terms of conventional prison privatization debates are undergirded by a bedspace epistemology in which the geographies of imprisonment are represented as a homogeneous, instrumental, and ahistorical space.

This raises an important geographic question: where, exactly, are the stakes of conventional prison privatization debates located? The literature reviewed here suggests that a public-private binary is imposed by the terms of conventional privatization debates, pitting "the public" versus "the private" interest in nondialectical terms against one another. This is, in my view, an empirical and analytical shortcom- ing. A growing body of literature argues that private prisons should be analyzed as expansions of state capacity or publicprivate partnerships (Dolovich, 2005; Gilmore and Gilmore, 2008; White, 2001). At the same time, a growing cohort of geographers is recasting these processes in explicitly relational terms, which can shed light on privatization in considerably different terms. I turn now to a review of their work.

\subsection{Carceral geographies}

Researchers have used the term "carceral geography" to describe spatially attuned engagements with imprisonment and migrant detention (Moran et al., 2013:1). The emerging subfield has grown considerably over the past decade (Bonds, 2006; Gilmore, 2007; Loyd et al., 2012; Martin and Mitchelson, 2009; Turner, 2013). Carceral geographers might make three particularly noteworthy contributions to prison privatization debates, although they are generally absent from the prison privatization literature. The specific contributions can be thought of as accounting for (or reanalyzing): geographic relationality, criminalization, and humanism in the context of prisons. Each of these contributions has significant implications for reframing the terms of the prison privatization debates and bedspace.

Most carceral-geographic work observes and analyzes the spatial interdependencies through which prisons are produced and sustained through a lens of geographic relationality, despite the prison's persistent appearance as the paradigmatic container-space (Martin and Mitchelson, 2009; Moran et al., 2013). That is to say that no prison - regardless of how high its walls - is spatially autonomous from its geographic setting. This challenges the generally a-spatial terms of prison privatization debates, and the nondialectical epistemology of bedspace in crucial ways. Carceral geographies consistently challenge the inside/outside binarism of the "total institution" thesis (Baer and Ravneberg, 2008), for example, creating a more spatially robust accounting of the carceral context in which the prison is situated. They have often done so by accounting for the local, regional, and international locations of particular prisons (Baer and Ravneberg, 2008; Bonds, 2012; Mitchelson, 2011, 2012). They have also done so by analyzing the economic and social relationality through which prisons are produced, with particular attention to racialization (Bonds, 2013; Che, 2005; Gilmore, 2007; McKittrick, 2012). This research socially denaturalizes and politically deneutralizes the prison, in contrast to conventional prison privatization debates (Dolovich, 2009). It also "opens" the prison - whether public or private - to questions beyond ownership or management, permitting critiques of the institution itself. It also imposes a fundamentally geographic research question: who is where, and why?

Questions about the coerced mobility of prisoners (Clear, 2007; Mitchelson, 2012) have led carceral geographers to emphasize the causes, contexts, enforcements, and outcomes of criminalization because it is always a precondition to im- 
prisonment or detention (Gilmore, 2007; Hiemstra, 2010; Loyd et al., 2010, 2012). Ruthie Gilmore, for example, has described private prison companies as "coming in the wake of an entire criminalization project rather than being the people who make it happen. They're not the ones who make it happen" (Loyd, 2012:44). Rather than accepting the prison as a natural, pre-given spatiality, like studies premised on geographic relationality, analyses of criminalization also question the nature of the prison itself. And, as most carceral geographers are at pains to emphasize, this matters incredibly because the prison is a fundamentally social space (i.e., there is nothing natural about a prison) and human captivity is undoubtedly "a crucial geographic paradigm" (McKittrick, 2006:xvi).

Geographers and others are contributing to an extensive humanistically sensitive body of research, at a time when prison ethnography has declined (Wacquant, 2002). Perhaps this more than any other body of research resists the homogenizing representations produced through a bedspace epistemology. Although much of the carceral geography literature adopts a political economy approach that is often structural in its analysis (Turner, 2013), agency foregrounds a number of important studies (e.g., Moran et al., 2013:127-247). Scholars have paid particular attention to ways that the imprisoned "create their own spaces within [prisons and detention centers]; making them temporarily their own as they occupy and move through them" (e.g., Jewkes, 2013:128). Studies also account for various subjectivities that are specifically constructed in carceral settings (Moran et al., 2009; Shabazz, 2009; Valentine and Longstaff, 1998). Carceral geographies have also accounted for prisoners' loved and loving ones, who are "part of" carceral institutions despite their distance from the imprisoned (Gilmore, 1999, 2007; Moran et al., 2012; Pallot, 2007).

Collectively, this work fills an important void because there is little room for everyday life or humanity in conventional prison privatization debates (Dolovich, 2009), or in bedspace as a representation of imprisonment. But, if a bedspace is not grounded in a carceral geography that is socio-spatially relational and fully humanized, then to what type of space does this representation refer? My argument is that bedspace is an empirically, analytically, and ethically problematic spatial abstraction that is produced through commodification and bureaucratization. I turn now to an empirical report and analysis of the spatialities presented in private prison firm writings in support of that claim.

\section{Empirics and analysis: producing bedspace}

I organize my principal findings around two themes, both of which are premised on the representation of imprisonment as bedspace. First, I emphasize the commodification of imprisonment implicit in representations of prison space as a marketplace of homogeneous beds, structured by supply and demand, and measurable in terms of inventory. Second, I consider the bureaucratization of that economically instrumental marketplace as it is "consumed" by jurisdictions at a variety of scales, adapted and applied to social spaces beyond the prison, and represented as ceaselessly expansive in its potential. Although I treat them in separate sections for heuristic purposes, the commodification and bureaucratization of imprisonment should be understood as co-producers of bedspace; any representation of imprisonment cited below involves both processes, often simultaneously. Please note that, unless specified otherwise, all points of emphasis (e.g., bold font) have been added.

\subsection{Bedspace and the commodification of imprisonment}

The documents analyzed consistently present prison privatization as a bedspace market. For example, one of the Geo Group leadership's annual letter to shareholders explains that "[Geo Group] believe that our core correctional, detention, and treatment market segments continue to be driven by strong fundamental trends and increasing demand for bed space" (Geo Group, 2011:2). These documents often invoke supply and demand as the means by which the bedspace market should be organized, and through which the firm's shareholders will be financially rewarded. This market is often explicitly linked to bedspace.

For example, a report entitled "The Flexible Corrections Solution to Supply and Demand" states that

We continue to benefit from a positive environment where the demand for prison beds exceeds supply, and we believe CCA is well positioned to take advantage of this market dynamic to continue building sharehold value (CCA, 2008:2) [emphasis added].

Similarly, Geo Group documents explicitly link their supply of bedspace to governmental demand:

...our core correctional, detention, and treatment market segments continued to be driven by strong fundamental trends and increasing demand for bed space. In the United States, capacity and budget constraints have continued to drive the need for cost- efficient correctional beds (Geo Group, 2011:2) [emphasis added].

Represented in this way, the bedspace market is seemingly straightforward. Firms such as CCA and the Geo Group provide a supply of bedspace to governmental actors and institutions with a demand for that supply, and market signals establish the price of an exchange in both parties' best interest.

From this vantage point, inventories of beds are crucial, and are promoted by firms as signs of market prowess and potential revenues. For example, CCA (2005:4) explains that 
Our inventory of available beds provides a "just-intime" solution to our customers' corrections needs, without the requirement of the large capital outlays typically involved in adding prison capacity. CCA also has the ability to expand existing facilities to accommodate needs not met by our existing inventory of beds [emphasis added].

These rhetorical terms of supply/inventory and demand/needs discursively produce a bedspace market. In this market, private prison firms represent themselves as the producer, governmental customers are the consumer, and bedspace is the commodity exchanged.

In addition to rhetorically aligning prison privatization with "neoliberal" crime, punishment, and economic order (Herbert and Brown, 2006; Jones and Popke, 2010), the discursive construction of this bedspace market demonstrates two characteristics of abstract space that are particularly useful for prison industrialists and the state alike. First, bedspace produces a re-envisioned practice of imprisonment that is politically neutral by means of its social emptiness. Lefebvre referred to such abstractions as, "an ideology in action - an empty space, a space that is primordial, a container ready to receive fragmentary contents, a neutral medium into which disjointed things, people and habitats might be introduced" (Lefebvre, [1974] 1991:308 [italics in original]). The closest we come to a humanist sensibility or the concrete space of imprisonment is through the term "inmate" in these writings; no one in a prison is named. And, if the geographies of imprisonment are accepted on these terms, there is no prison privatization debate to be won or lost in terms of legitimacy or humanity (Dolovich, 2009).

Second, bedspace presents itself as an erasure of geographic difference and localization; instead, it presents a series of uniform partitions cut from an abstract, homogeneous space. Lefebvre argued that commodification and bureaucratization entail "homogenizing efforts" in the production of abstract space, and lamented the power of "the seemingly homogeneous mass of politically controlled space" that results from abstraction ([1974] 1991:64). Such a representation stands in stark contrast to the relational prison space advocated by carceral geographies. Instead, bedspace is consistently represented as an entirely exchangeable and generally fungible space. And, as Jones and Popke's research (2010:118) implies, once bedspace becomes an economically and politically acceptable spatial epistemology, the abstraction appears to pre-exist all other spatialities of imprisonment (at least for those who adopt and practice the epistemology). Bedspace becomes an entirely natural state of affairs.

So much, then, for the question of who is where, and why? The question of for whom bedspace operates, however, can be addressed in the firms' writings. I turn now to an analysis of this carceral commodity's consumption.

\subsection{Bedspace and bureaucratization}

These documents consistently represent state institutions as consumers of bedspace, reflecting the bureaucratizing processes associated with abstract space (Gregory, 1994:401406). The representations of imprisonment as a bedspace market above allude to multiple bureaucracies, spread across a remarkable number of jurisdictions. Both firms hold prisoners on behalf of several federal entities, and dozens of state and local governments. For example, CCA explain themselves as a "provider to federal, state, and local governmental agencies” (2013a:1). Geo Group documents describe

... worldwide operations included the management and/or ownership of approximately 77,000 beds at 98 correctional, detention and re-entry facilities, including idle facilities and projects under development and also included the provision of monitoring more than 70,000 offenders in a community-based environment on behalf of approximately 900 federal, state, and local correctional agencies located in all 50 states (Geo Group, 2014:4) [emphasis added].

Once commodified and politically neutralized, it seems that bedspace can be exchanged in any jurisdiction-asmarketplace.

These documents also suggest a potent capacity of bedspace in relation to its customer base: bedspace appears to be geographically mobile and ceaselessly expansive. Contrary to the steel, concrete, and barbed wire that characterize the built environment of a prison's social space, bedspace is a relatively mobile phenomenon premised on capital flows. Because its abstract commodity form is not fixed to a given location, bedspace can traverse the jurisdictional scales and sites - of contemporary statecraft as quickly as prison space can be built, bought, sold, or leased. For example, Geo Group writings suggest that bedspace is already adaptable to (and adoptable in) an international setting. Their documents describe "a remarkable public-private partnership" in South Africa, "as new public-private partnerships are explored to alleviate the country's growing demand for correctional bed space". And CCA (2013b:10) links "long-term growth opportunities" to "certain customers" before claiming their belief that their business can be further developed by, "maintaining and expanding our customer relationships and continuing to fill existing beds within our facilities, while maintaining an adequate inventory of available beds" (Geo Group, 2006:18).

As abstract space, bedspace thus simultaneously reflects "the power of money and that of the political state" (Lefebvre, [1974] 1991:52) in a medium that can grow the spatial extent and intensity of both economic and political power. However, despite large bases of customer states, and demonstrated abilities to expand the material landscape that underpins their market, the "growth narratives" of private prison 
firms are often presented in ahistorical terms. This raises two points regarding the histories of the firms themselves to which I turn now, and a larger discussion of their customers (i.e., the state) to which I turn in the paper's final section.

The first point to be raised regarding histories of private prison firms is that their growth narratives often obscure well-documented levels of economic uncertainty and financial instability. For example, Culp (2005) has argued that prison privatization experienced a process of resurgence, followed by growth, and then stagnation between 1984 and 2000. Reporting for the Washington Post before 11 September 2001, Slevin (2001:A03) wrote of "an industry whose grand expectations... outpaced its ability to deliver", noting that "CCA's stock bottomed at 18 cents per share in December, after trading as high as USD 44 in 1998". Several years later, Ruthie Gilmore argued that "Despite boosterish claims by stock analysts, private prison firms consistently hover on the brink of disaster" (2007:22). Despite representations of bedspace as a homogeneous, empty space, this uncertainty and instability implicates an entirely human geography.

For private prison firms, human occupancy is a necessary condition for sustaining revenue streams and profitability. As Hallett has argued, "prisoners are no longer profitable solely for their labor, but for their bodily ability to generate per diem payments for their private keepers" (2006:4). Owners of empty prisons most often go unpaid, and investors generally discipline emptiness severely. In this sense, private prison firms are like motels, opera houses, and university lecture halls - or, like human warehouses (Irwin, 2005) in that they must be occupied in order for their exchange value to be realized. An empty prison is like a stockpile of unsold inventory for firms, devalued; and, the same inventory that demonstrates economic prowess and potential profits during rounds of carceral expansion is economically devastating during rounds of decarceration. The fact that firms cannot manufacture occupancy for themselves raises another historical question: from where does occupancy come?

This raises a second point regarding the histories of private prison firms. As carceral geographies have attested, criminalization - the regulation of which is monopolized by the state - is a precondition of imprisonment and detention. This necessarily confounds representations of imprisonment as a neutral, homogeneous bedspace market in which entrepreneurial firms simply produce and then states consume, because it foregrounds the state's "production" of criminalized bodies as a precondition to the state's eventual "consumption" of bedspace. In other words, a bedspace epistemology obscures prison firms' clear dependence on states as both the producers and consumers of for-profit imprisonment. For example, CCA documents report that

A decrease in occupancy levels could cause a decrease in revenues and profitability... We are dependent upon the governmental agencies with which we have contracts to provide inmates for our managed facilities. We cannot control occupancy levels at our managed facilities (CCA, 2009:20) [emphasis added].

And where beds and their occupants finally intersect, the stakes (Jones and Popke, 2010) of either adopting or resisting a bedspace epistemology become clearer:

... facility contribution at our 1,824-bed Tallahatchie County Correctional Facility [Mississippi, USA] deteriorated by approximately $\$ 1.8$ million during 2007 from 2006 as a result of the movement of Hawaiian inmates from the Tallahatchie facility to the Saguaro facility [Arizona, USA]... the decline in occupancy at this facility from an average of $91 \%$ in 2006 to an average of $78 \%$ in 2007 resulted in a temporary reduction in operating margin until such time as the beds are filled with replacement inmates (CCA, 2008:20 [locations added]).

In short, no firm profits "until such time as the beds are filled" with human beings. Or, no firm profits until the abstraction of bedspace is concretely imposed upon human life. In this sense, all "private" prisons are expansions of the state's capacities to criminalize and wield a monopoly on violence.

In their account of Lefebvre's writings on the state, Brenner and Elden (2009:358-361) emphasize three dimensions of abstract space that are noteworthy in this context. First, they characterize abstract space as "the political product of state spatial strategies"; and, second, they argue that this political product "involves new ways of envisioning, conceiving, and representing the spaces in which everyday life, capital accumulation, and state action are to unfold" (Brenner and Elden, 2009:359). If bedspace exemplifies abstract space, then states should be actively participating in its production. This appears to be the case, as state entities consistently adopt a bedspace epistemology in their proceedings and publications; for example, the 108th Congress:

... the Secretary of Homeland Security shall increase by not less than 8,000 , in each of the fiscal years 2006 through 2010, the number of beds available for immigration detention and removal operations of the Department of Homeland Security above the number for which funds were allotted the preceding fiscal year (Public Law 108-481, 2004:Sec. 5204) [emphasis added].

I have found forms of bedspace in documents from prison systems in all fifty US states and every federal entity with the jurisdiction to incarcerate (e.g., Department of Homeland Security Office of Inspector General, 2009; Federal Bureau of Prisons, 2002; Renfrow et al., 2004). It is clear that many state entities discursively co-produce bedspace as a representation of imprisonment, in alignment with the first two of Brenner and Elden's (2009) points of emphasis. 
Brenner and Elden's third point of emphasis regarding abstract space is particularly salient in the context of imprisonment. By their reading of Lefebvre, abstract space is "inherently violent and geographically expansive" (Brenner and Elden, 2009:359). The promise of growth - and implicit geographic expansion - is the clear focus of many pages in the documents analyzed. But, what of the violence suggested by Brenner and Elden? In the following section, I contend that the most dangerous characteristic of bedspace is that it belies a vast and destructive geography of violence.

\section{Discussion: violence and bedspace}

Lefebvre argued that abstract space internalizes an important contradiction "between the appearance of security and the constant threat, and indeed the occasional eruption, of violence" ([1974] 1991:57). As McCann's (1999) work demonstrates, the construction of consent as to what activities are suitable in a given place is a central aim for producers of abstract space. And, despite the multitude of documented horrors that are experienced during imprisonment (e.g., Shapiro, 2011:24-29), there is very little room for "violence" in the production of bedspace. In fact, the word "violence" does not appear on any of the more than 2200 pages of documents analyzed for this study; although, the phrase "violent situations" appears once (Geo Group, 2005:22); and, "sexually violent predator" and "sexually violent offender facilities" together appear roughly one dozen times (e.g., Geo Group, 2008:18, 22).

By contrast, the word "disturbance" appears at least once in nearly every document analyzed. As CCA leaders explain to shareholders, "Our company experienced several inmate disturbances at a number of our facilities during 2004. While disappointing, inmate disturbances are an unfortunate part of our business" (CCA, 2005:5). I understand "disturbance" as a noun meaning "the interruption or breaking up of tranquility, peace, rest, or settled condition; agitation (physical, social, or political)" (Oxford English Dictionary, 2013). Bedspace - a politically instrumental representation of space that functions as an abstraction of imprisonment - indeed presents itself as a "settled condition". However, images of tranquility, peace, and rest stand in stark contrast to other characterizations of prisons, for example, as "cages" (Loyd et al., 2012), or "violent places" (Dolovich, 2009:130), or sites of "the slow death of inmates, racial violence, and the spatial management of race", or "urbicidal geographies that deliberately harm a particular population" (McKittrick, 2012:955-956).

When the security of bedspace is threatened, "disturbance" is used most often in reference to the potential for property damage or litigation in a firm's facilities. In the rare event that a specific "disturbance" is described, it is generally discussed in exclusively operational terms, as "results of operations". For example,
During July 2004, an inmate disturbance at the Crowley County Correctional Facility located in Olney Springs, Colorado resulted in damage to the facility, requiring us to transfer a substantial portion of the inmates to other of our facilities and to facilities owned by the state of Colorado... the impact was mitigated by the recovery of $\$ 1.0$ million of business interruption and other insurance proceeds recognized during the first quarter of 2005. As of December 31, 2005, we housed 1,144 inmates at this facility... largely due to an expansion of the Crowley facility by 594 beds completed during the third quarter of 2004 [i.e., in less than 3 months from the riot]. Our overall inmate populations from the state of Colorado have also recovered. We housed 3,408 inmates from the state of Colorado as of December 31, 2005, compared with 2,882 inmates just prior to the inmate disturbance at the Crowley facility (CCA, 2007:27).

Viewed from this vantage point, despite "the inmate disturbance at the Crowley facility", bedspace expanded by 594 beds and, overall inmate populations were recovered. Bedspace appears to have resumed its settled condition.

In a Colorado Department of Corrections report on the Crowley facility riot (Renfrow et al., 2004:8-9), the authors make the following argument regarding the history of privatization in their state:

The private prison industry is driven by a need created when the number of inmates exceeds the number of state owned beds. Simply, the public expects to be protected; if no state funds are available for prison construction, a market for private prisons exists, based upon the need for bed space at any given time. Arguments can be made for and against the concept of private prisons. However, as of this date, due to the lack of sufficient public beds, the choice is stark; approximately 2,797 Colorado felons can either be placed in private facilities, in out of state facilities or on the street.

Like CCA or Geo Group documents, this report produces a bedspace market that is politically and economically instrumental. For example, the first sentence of the report's Conclusions and Recommendations section reads, "After any prison disturbance, hindsight is useful for drawing conclusions about missed operational opportunities" (Renfrow et al., 2004:65).

However, this report's authors do not - perhaps cannot - deny glimpses of the riot's violence (Tyner and Inwood, 2014). We are told that emergency responders used: five shotguns; 700 rounds of various ammunition, such as 50 rounds of "RP23 (non-lethal)" or 120 rounds of "buckshot"; 36 grenades; several liters of tear gas; more than a dozen cans of pepper spray or pepper fogger; 3100 sets of flex cuffs; and 
a canine unit that was "utilized for crowd control and to clear buildings" (Renfrow et al., 2004:55-56). We learn that, "19 inmates were treated for serious injuries and no staff injuries were reported. Numerous other inmates were treated for less severe injuries" (Renfrow et al., 2004:55). And the horrific results of one "inmate assault" are described as follows:

The inmate was secured in his cell; however, other inmates rammed his door with weight bars and set the wooden door on fire. Once the door had been defeated, perpetrators stabbed the inmate, struck him with weight bars, beat him and threw him off the second tier of the living unit. Inmates accosted the severely injured inmate again while he lay on the first floor and struck him on the head with a microwave oven, leaving him for dead (Renfrow et al., 2004:62).

I want to conclude by arguing that it takes considerable political and economic energy - along with tragic levels of public callousness and consent - to reproduce imprisonment as a market of homogeneous beds amidst such violence. As Lefebvre argued, such an abstraction must be disguised as an empty space, although "nothing could be more false" ([1974] 1991:289) than this emptiness. Geographies of imprisonment are always human geographies. In turn, there is nothing natural or neutral about bedspace. Like other forms of abstract space, bedspace is extremely dangerous and it should be held to the very highest levels of scrutiny and resistance.

Acknowledgements. The National Science Foundation supported this research through DDRI award \#0727443. Thank you to Jen Turner for her editorial guidance, and to this paper's anonymous reviewers for their generous and productive feedback. Steve Holloway, Nik Heynen, Hilda Kurtz, Amy Ross, and Ron Mitchelson invested in early drafts. Joshua Barkan tirelessly (and politely) demanded The Argument. Mona Domosh, Jeff Popke, and Katherine Jones helped me to see it. Each of you had a strong, positive impact on this work; despite its shortcomings, which are entirely my own.

Edited by: J. Turner

Reviewed by: two anonymous referees

\section{References}

Austin, J. and Coventry, G.: Are we better off: comparing private and public prisons in the United States, Current Issues in Criminal Justice, 11, 177-201, 1999.

Baer, L. D. and Ravneberg, B.: The outside and inside in Norwegian and English prisons, Geogr. Ann. B, 90, 205-216, 2008.

Bates, E.: Private prisons, Nation, 1, 11-16, 1998.

Bonds, A.: Profit from punishment? the politics of prisons, poverty and neoliberal restructuring in the rural American Northwest, Antipode, 38, 174-177, 2006.
Bonds, A.: Building prisons, building poverty: prison sitings, dispossession, and mass incarceration, in: Beyond Walls and Cages: Prisons, Borders, and Global Crisis, edited by: Loyd, J., Mitchelson, M., and Burridge, A., The University of Georgia Press, Athens, GA, 2012.

Bonds, A.: "Yes in my backyard" politics and the racialized reinvention of Madras, Oregon, Ann. Assoc. Am. Geogr., 103, 13891405, 2013.

Brenner, N. and Elden, S.: Henri Lefebvre on state, space, territory, International Political Sociology, 3, 353-377, 2009.

CCA: 2004 Annual Report, Corrections Corporation of America, Nashvill, TN, 2005.

CCA: 2006 Annual Report, Corrections Corporation of America, Nashville, TN, 2007.

CCA: 2007 Annual Report, Corrections Corporation of America, Nashville, TN, 2008.

CCA: 2008 Annual Report, Corrections Corporation of America, Nashville, TN, 2009.

CCA: 2012 Annual Letter to Shareholders, Corrections Corporation of America, Nashville, TN, 2013a.

CCA: 2012 Annual Report on Form 10-K, Corrections Corporation of America, Nashville, TN, 2013b.

CCA: 2013 Annual Report, Corrections Corporation of America, Nashville, TN, 2014.

Che, D.: Constructing a prison in the forest: conflicts over nature, paradise, and identity, Ann. Assoc. Am. Geogr., 95, 809-831, 2005.

Clear, T. R.: Imprisoning communities: how mass imprisonment makes disadvantaged neighborhoods worse, Oxford University Press, Oxford, 2007.

Clear, T. R. and Frost, N. A.: Editorial introduction: private prisons, Criminology and Public Policy, 1, 425-426, 2002.

Culp, R. F.: The rise and stall of prison privatization: an integration of policy analysis perspectives, Criminal Justice Policy Review, 16, 412-442, 2005.

Department of Homeland Security Office of Inspector General: Immigration and Custom Enforcement Detention Bedspace Management, U.S. Department of Homeland Security, Washington, DC, 2009.

Dilulio, J. and John, J.: What's wrong with private prisons?, Public Interest, 92, 66-83, 1988.

Dolovich, S.: How privatization thinks: the case of prisons, in: Government by Contract: Outsourcing and American Democracy, edited by: Freeman, J. and Minow, M., Harvard University Press, Cambridge, MA, 2009.

Dolovich, S.: State punishment and private prisons, Duke Law J., 55, 437-546, 2005.

Federal Bureau of Prisons: Federal Bureau of Prisons Management of Construction Contracts, Audit Report 02-32, Office of the Inspector General, Washington, DC, 2002.

GAO-GGD: Private Prisons: Cost Savings and BOP's Statutory Authority Need to Be Resolved, United States General Accounting Office-General Government Division, Washington, DC, 1991.

GAO: Cost of Prisons: Bureau of Prisons Needs Better Data to Assess Alternatives for Acquiring Low and Minimum Security Facilities, United States Government Accountability Office, Washington, DCGAO-08-6, 2007.

Garland, D. (Ed.): Mass Imprisonment: Social Causes and Consequences, Sage Publications, London, UK, 2001. 
Geo Group: 2004 Annual Report, The GEO Group, Inc., Boca Raton, FL, 2005.

Geo Group: 2005 Annual Report, The Geo Group, Inc., Boca Raton, FL, 2006.

Geo Group: 2006 Annual Report, The Geo Group, Inc., Boca Raton, FL, 2007.

Geo Group: 2007 Annual Report, The Geo Group, Inc., Boca Raton, FL, 2008.

Geo Group: 2010 Annual Report, The GEO Group, Inc., Boca Raton, FL, 2011.

Geo Group: 2013 Annual Report, The GEO Group, Inc., Boca Raton, FL, 2014.

Gilmore, R. W.: You have dislodged a boulder: mothers and prisoners in the post Keynesian California landscape, Transforming Anthropology, 8, 12-38, 1999.

Gilmore, R. W.: Golden Gulag: Prisons, Surplus, Crisis, and Opposition in Globalizing California, University of California Press, Berkeley, 2007.

Gilmore, R. W. and Gilmore, C.: Restating the obvious, in: Indefensible Space: The Architecture of the National Insecurity State, edited by: Sorkin, M., Routledge, New York, 2008.

Greene, J. A.: Comparing private and public prison services and programs in Minnesota: findings from prisoner interviews, Current Issues in Criminal Justice, 11, 202-232, 1999.

Gregory, D.: Geographical Imaginations, Blackwell, Cambridge, MA, 1994.

Hallett, M. A.: Private Prisons in America: A Critical Race Perspective, University of Illinois Press, Urbana and Chicago, 2006.

Harding, R.: Prison privatization: the debate starts to mature, Current Issues in Criminal Justice, 11, 109-118, 1999.

Herbert, S. and Brown, E.: Conceptions of space and crime in the punitive neoliberal city, Antipode, 38, 755-777, 2006.

Hiemstra, N.: Immigrant "illegality" as neoliberal governmentality in Leadville, Colorado, Antipode, 42, 74-102, 2010.

Irwin, J.: The Warehouse Prison: Disposal of the New Dangerous Class, Roxbury Publishing Company, Los Angeles, 2005.

Jewkes, Y.: On carceral space and agency, in: Carceral Spaces: Mobility and Agency in Imprisonment and Migrant Detention, edited by: Moran, D., Gill, N., and Conlon, D. (Eds.), Ashgate, Surrey, UK, 2013.

Jones, K. T. and Popke, E. J.: Re-envisioning the city: Lefebvre, Hope VI, and the neoliberalization of urban space, Urban Geogr., 31, 114-133, 2010.

Lefebvre, H.: The Production of Space, Blackwell, Malden, MA, [1974] 1991.

Loyd, J.: Race, capitalist crisis, and abolitionist organizing: an interview with Ruth Wilson Gilmore, in: Beyond Walls and Cages: Prisons, Borders, and Global Crisis, edited by: Loyd, J., Mitchelson, M., and Burridge, A., The University of Georgia Press, Athens, GA, 2012.

Loyd, J., Burridge, A., and Mitchelson, M. L.: Bridging immigrant justice \& anti-prison organizing in the United States, Social Justice, 36, 85-103, 2010.

Loyd, J. M., Mitchelson, M., and Burridge, A. (Eds.): Beyond Walls and Cages: Prisons, Borders, and Global Crisis, The University of Georgia Press, Athens, GA, 2012.

Martin, L. and Mitchelson, M. L.: Geographies of detention and imprisonment: interrogating spatial practices of confinement, disci- pline, law, and state power, Geography Compass, 3, 459-477, 2009.

McCann, E.: Race, protest, and public space: contextualizing Lefebvre in the U.S. city, Antipode, 31, 163-184, 1999.

McKittrick, K.: Demonic Grounds: Black Women and the Cartographies of Struggle, University of Minnesota Press, Minneapolis, MN, 2006.

McKittrick, K.: On plantations, prisons, and a black sense of place, Soc. Cult. Geogr., 12, 947-963, 2012.

Mitchelson, M. L.: 'Alcatraz in the sky': engineering Earth in a Virginia (USA) prison, in: Engineering Earth, edited by: Brunn, S. D., Springer, New York, NY, 2011.

Mitchelson, M. L.: The urban geography of prisons: mapping the city's "other" gated community, Urban Geogr., 33, 147-157, 2012.

Moran, D., Gill, N., and Conlon, D. (Eds.): Carceral Spaces: Mobility and Agency in Imprisonment and Migrant Detention, Ashgate, Surrey, UK, 2013.

Moran, D., Pallot, J., and Piacentini, L.: Lipstick, lace, and longing: constructions of femininity inside a Russian prison, Environ. Plann. D, 27, 700-720, 2009.

Moran, D., Piacentini, L., and Pallot, J.: Disciplined mobility and carceral geography: prisoner transport in Russia, T. I. Brit. Geogr., 37, 1-21, 2012.

Oxford English Dictionary: "disturbance, n.”, OED Online, Oxford University Press, 4 July 2014, 2013.

Pallot, J.: "Gde muzh, tam zhena" (where the husband is, so is the wife): space and gender in post-Soviet patterns of penality, Environ. Plann. A, 39, 570-589, 2007.

Public Law 108-481: Intelligence Reform and Terrorism Prevention Act of 2004, 108th Congress of the United States of America, Washington, DC, 2004.

Renfrow, N., Greco, C., and Cooper, A.: Inmate Riot: Crowley Correctional Facility July 20, 2004 (After Action Report), Colorado Department of Corrections, Denver, CO, 2004.

Shabazz, R.: So high you can't get over it, so low you can't get under it: carceral spatiality and black masculinity in the United States and South Africa, Souls, 11, 276-294, 2009.

Shapiro, D.: Banking on Bondage: Private Prisons and Mass Incarceration, American Civil Liberties Union, New York, NY, 2011.

Shichor, D.: Private prisons in perspective: some conceptual issues, The Howard Journal, 37, 82-100, 1998.

Slevin, P.: Prison firms seek inmates and profits, Washington Post, Washington, DC, A03, 18 February, 2001.

Taylor, P. and Cooper, C.: "It was absolute hell": inside the private prison, Capital and Class, 96, 3-30, 2008.

Turner, J.: Disciplinary engagements with prisons, prisoners and the penal system, Geography Compass, 7, 35-45, 2013.

Tyner, J. and Inwood, J.: Violence as fetish: Geography, Marxism, and dialectics, Prog. Hum. Geogr., 35, 1-14, 2014.

Valentine, G. and Longstaff, B.: Doing porridge, J. Mat. Cult., 3, 131-152, 1998.

Wacquant, L.: The curious eclipse of prison ethnography in the age of mass incarceration, Ethnography, 3, 371-397, 2002.

White, A. A.: Rule of law and the limits of sovereignty: the private prison in jurisprudential perspective, Am. Crim. Law Rev., 38, 111-146, 2001. 